\title{
19. Power, control and the protean career: a critical perspective on multinational organizations' permanent international assignees
}

Marian Crowley-Henry and David Weir

\section{INTRODUCTION}

Mainstream management literature and research regarding the international career has long focused on the traditional expatriate experience (for example Adler 1986; Boyacigiller 1995; Dowling and Welch 2004; Feldman and Tompson 1993; Mendenhall and Oddou 2000). In this discourse, the tendency has been to outline the benefits and issues to be considered for organizations and individuals embarking on international assignments. In contrast, this chapter focuses on a special group whose positioning in the structures of employment and organization is in some ways exemplary of developing trends in the global labor force. They are the highly educated permanent expatriates ${ }^{1}$ who remain in the host country indefinitely (that is without a pre-determined organizational option of repatriation to their initial home country). We engage with the mainstream ways of dealing with this group and take a critical approach in exploring their international careers. In fact, we take a critical stance on the notion of 'career' itself and question its ubiquitous application. Adopting a loose and critical review of Foucault's governmentality, technologies of power and domination and technologies of the self, we aim to explore organizational and individual power and control with regard to an individual's career in an international context, and to propose a practical model for professionals working in areas such as human resource management (HRM), human resource development (HRD) and career management consultancy. 


\section{POWER, CONTROL AND CAREER - AN OVER VIEW}

Our intention in this chapter is to problematize an aspect of organizational structuring and individual functioning that is central to the post-modern situation, involving as it does aspects of organizational process and actor identity as well as the discourse of management development: that of the 'career'. It is central to current managerialist discourse because it is seen as something to be controlled, managed and expropriated in terms of organizational value. It is central to conceptions of individual identity because it figures in many counter-narratives in relation to struggle, rejection and transcendence. It is implicated in the discourse of social power and personal fulfilment.

We take the task of a critical stance on conventional theorizing and practice as being that of engaging with the assumptions of the received discourse and illustrating that other narratives, other takes on these situations are possible and therefore other practices can be supported.

Foucault recognizes that ' $[t]$ he relations of power are perhaps among the best hidden things in the social body' (1990, p. 169). He asks the fundamental questions:

Who exercises power? How? Who makes decisions for me? Who is preventing me from doing this and telling me to do that? I don't believe that this question of "who exercises power?" can be resolved unless that other question "how does it happen?" is resolved at the same time (Foucault 1990, p. 103).

Deetz argues that there is a 'constant reconfiguration of power relations' (1998, p. 153). The roles of all involved need to be considered since '[n]o matter how much power one appears to accumulate, it is always necessary to obtain it from the others who are doing the action' (Latour 1986, p. 276). In this chapter, organizational control over one's career is examined, and the extent to which individuals appropriate power and master their own career in a socially constructed and norm-imposed world is considered.

We analyse the personal experience of what in the conventional narratives would appear to be 'career management' or 'personal development' and conclude that neither of the two master or meta-narratives - of power, domination and control or of individual rejection or fulfilment - sufficiently comprise the complex reality of the protean career, and thus policies and practices based on these simplistic narratives are flawed and inadequate.

Larsen and Ellehave (2000, p. 104) have penned a comprehensive definition of career:

Career is the overall pattern of a continuous development process, by which an individual, via an interactive and interdependent relationship with an organizational environment, experiences and makes sense out of a sequence of 
critical events, activities and situations, through which competence is acquired, meaning is created, and projections for the future are made. The gradually unfolding career contains changes visible to others (the objective career) and changes in the individual's perception of her/his activities and identity (the subjective career). The two aspects form a duality, becoming inseparable.

They stress the interdependency of the objective and subjective career, both needing attention when researching careers. The objective career concerns the objective criteria by which ongoing success is judged (Mallon 1999, p. 363), whereas the subjective career is concerned with reaching objectives, fulfilment, self-conception, identity, work attitudes, personal choice and responsibility, and autonomy (Weick and Berlinger 1989 pp. 320-321; see also Van Maanen and Schein 1977).

Weick (1996) argues that given the shift in recent decades toward more transactional rather than relational psychological contracts (see also Rousseau 1995), future careers will be more concerned with internal, self-generated guides, such as growth, learning, and integration' (1996, p. 40). Gratton and Hope Hailey (1999) echo that there is 'a move towards a more individualistic notion of careers' (p. 79). The governmentality (Foucault 1982) of careers is questioned here, particularly with regard to the technologies of power and domination and the technologies of the self (Martin, Gutman and Hutton 1988). The objectification of individuals within organizations following a professional career is critiqued by a suggested movement toward the subjectification (Rose 1996) of individuals, which we interpret from the concept of the protean career and from the findings presented later in this chapter. We argue that there is a movement away from careers being narrowly defined and organizationally managed (Kahn 1996) to employees managing and making sense of their own careers within the wider context of their lives. This chapter looks at the extent to which this applies to a sample of international assignees on local country contracts with multinational organizations.

We use the notion of the 'protean career' in the sense used by Hall (1976, p. 201; also cited in Hall and Harrington 2004), who describes the protean career as follows:

The protean career is a process which the person, not the organization, is managing. It consists of all the person's varied experiences in education, training, work in several organizations, changes in occupational field, and so on. The protean person's own personal career choices and search for self-fulfillment are the unifying or integrative elements in his or her life. The criterion of success is internal (psychological success), not external.

Here the emphasis is on subjective success rather than objective success (position, salary). The reason for this is, because "professional identity 
may no longer play as dominant a role for such individuals, they are free to focus on other subidentities, such as family, community, or other personal interests' (Hall and Harrington 2004). People following the protean career concept 'are less concerned with ... organizational rewards and are more motivated by autonomy, personal values and psychological success' (Hall and Harrington 2004).

The protean career is so named from the Greek God Proteus, who was able to morph and change form at will. In career theory, the protean concept suggests a career path that can change gradually, serendipitously or completely depending on contingencies. We argue that Foucault's technologies of the self

which permit individuals to effect by their own means or with the help of others a certain number of operations on their own bodies and souls, thoughts, conduct, and way of being, so as to transform themselves in order to attain a certain state of happiness, purity, wisdom, perfection, or immortality' (Foucault 1988, p. 18, italics added)

materializes in the context of the protean career.

Control in the context of the protean career can for some writers mean realizing one's true identity - the 'authentic self' (Ashforth and Humphrey 1993, p. 97), or the 'core of self' (Hochschild 1983, p. 206). Turner sees that ' $[\mathrm{t}]$ he true self consists of deep, unsocialized, inner impulses. Mad desire and errant fancy are exquisite expressions of self' (1976, p. 992). Starkey and McKinlay (1998) advocate Foucault's later work, where he views individuals' and communities' own desires as paramount in the creation of their self-identities (Foucault 1977).

The notion of the protean career suggests that the individual attempts to take control of his/her work life. This contrasts with some other perspectives of people in the workforce, for example Braverman's contemporary worker, who is controlled by the capitalist organization (Braverman 1974, p. 107), and who experiences 'the progressive elimination of the control function of the worker, insofar as possible, and their transfer to a device which is controlled again insofar as possible, by management from outside the direct process' (Braverman 1974, p. 212). Indeed the struggle between Foucault's technologies of domination (in the guise of powerful multinational organizations in this instance) and technologies of the self (agency, how 'a human being turns him- or herself into a subject', (Foucault 1982, pp. 208-209) are developed here. It could be argued that other technologies of power and domination influence the technologies of the self. Historically cultivated beliefs regarding responsibilities to family members (for instance) impact to a greater or lesser degree on individuals at different periods of time, objectifying them to fitting in with societal expectations. 
The protean career is a direction where continual change dependent on contingencies leads the individual to a presentation of technologies of the self which morph and change shape accordingly.

Tension, according to Foucault, exists between individuals wishing to pursue an individual career, and the structural restrictions imposed on them by virtue of the context they are in. Giddens's work on structuration theory $(1979,1993)$ is relevant here in its stress on the interdependence between human agency and social structure. The individual may be perceived simplistically as master of his/her own destiny, but wider macro conditions also have a part to play, from economic to cultural (language) to wider family. Here, the complex nature of an individual's career within a social context is contingent on a number of elements, not least of which being the current market employment situation, which may tie an employee to an employer simply due to lack of alternative options and the need to have a regular income.

\section{THE STUDY}

This was an interpretive study in the sense that it considered individuals' subjective perceptions regarding their careers. The empirical material presented in the remainder of the chapter was derived from a larger study based on in-depth interviews with permanent international assignees (foreign residents) working for multinational organizations in the South of France.

Sophia Antipolis was the location of the geographical case study used. ${ }^{2}$ It is an international science and technology park located in the French Riviera. It houses over 1260 organizations (many of which have an international presence) and employs over 25000 people, and it is situated on the Côte D'Azur, a popular tourist destination with its sunny climate and Mediterranean/Alpine landscape. We took the approach that in a sense the location metaphored the organization and adopted the single case study (Stake 1998), with all respondents living and working within the same specific location, albeit for different multinational organizations.

Purposive sampling was used (Denzin and Lincoln 1998; Glaser and Strauss 1967), with the core sample linked to the case location, based on a snowball sample originating from the researchers' personal contacts. ${ }^{3} \mathrm{~A}$ limitation of the snowball sampling technique is that it can be 'an open invitation for sampling bias' (McQueen and Knussen 2002, p. 74). This study however included a broad cross-section of employees in the sample (see Table 19.1).

While we acknowledge the limitations of the methodology in this study, 


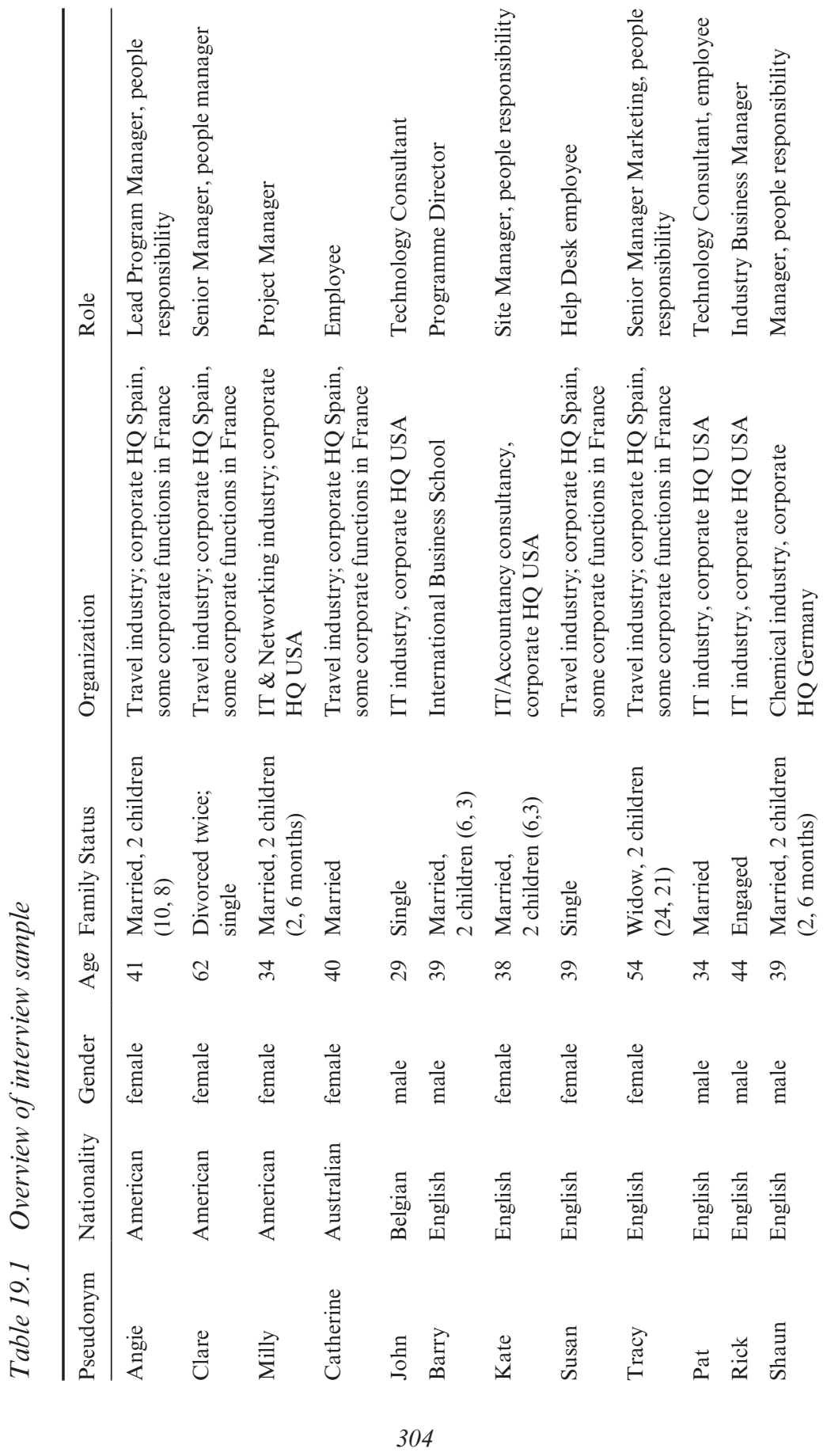



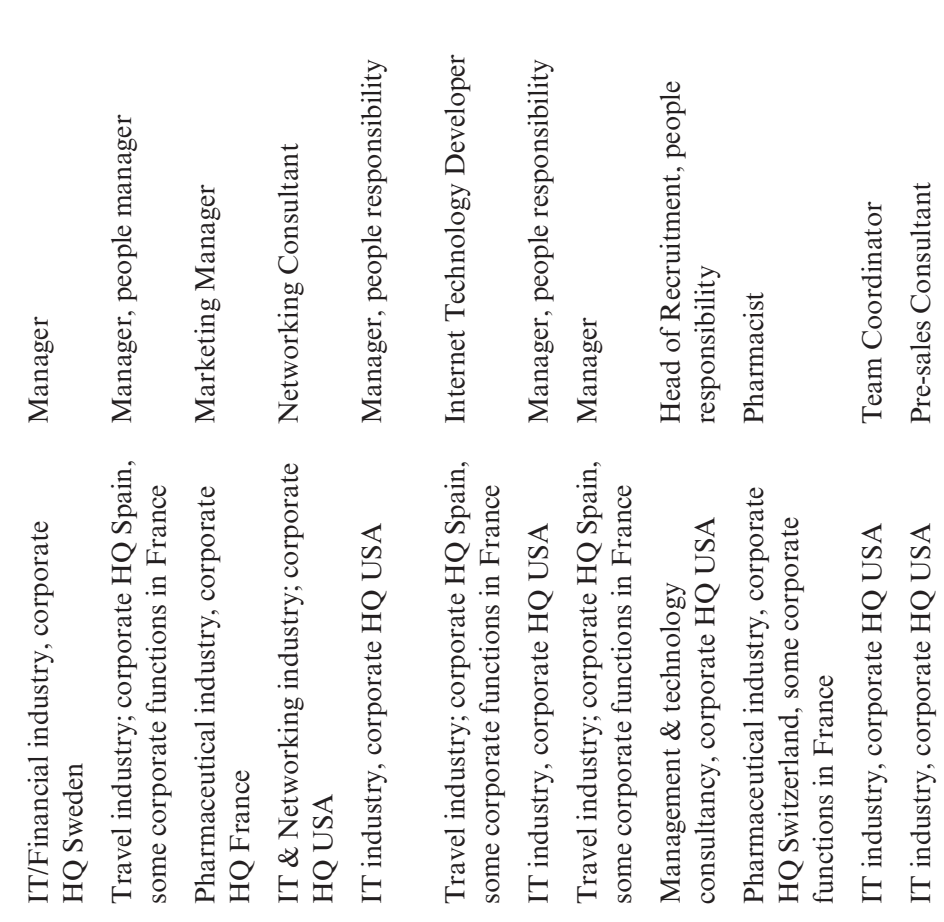

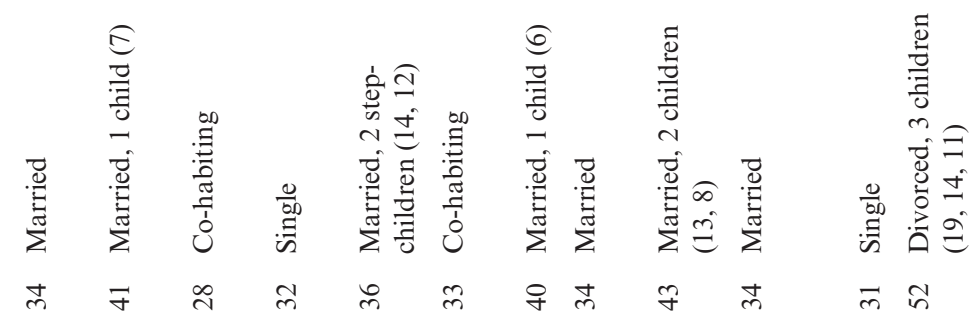

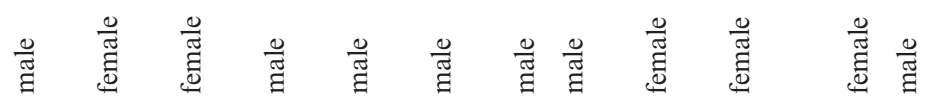

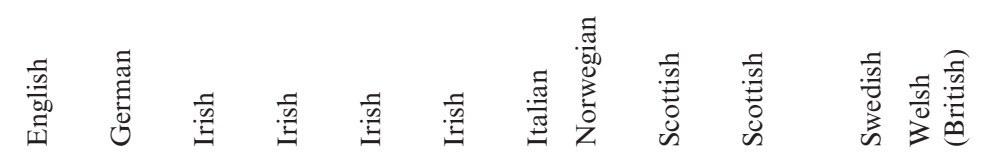

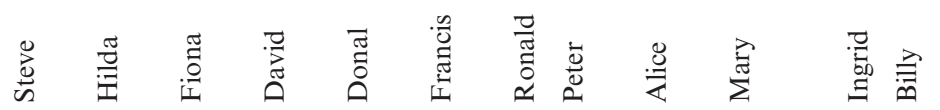
305 
we feel that the content raises interesting questions for comparison with other locations and categories of international assignees. It is hoped that 'readers will be able ... to generalize subjectively ... from the case in question to their own personal experiences' (Denzin and Lincoln 1998, p. xv).

\section{Power and Control - Empirical Findings}

It was clear in the research study that some interviewees in the sample noted the difficult current market situation, which limited alternative employment choices. As one respondent said, 'because in today's economic environment . . . it's just not that easy - you could easily find yourself, you know, without a job. So you don't have that luxury anymore . . . to just go like "OK ... I'll get a job anywhere"" (John, Belgian, 29 yrs). The boundaryless career which espouses the free movement of employees interorganizationally is not employee-friendly in this macro environmental situation of downsizing and cost-cutting.

Barry (English, $39 \mathrm{yrs}$ ) also noticed the structural shift in the area, where unemployment is commonplace: 'the jobs aren't around in Sophia like they used to be. So I think people are now choosing to come down here for life style reasons ... rather than career reasons'.

In this context, concertive power, the power of peers, was noted by the interviewees. One reported: 'Then you sort of hear: "well unemployment is so high. You should be happy that you have a job". If you complain about the stress, then . . . you hear "people who are unemployed ... would like to have the stress that you're saying you've got"' (Tracy, English, 54 yrs). Here the concertive pressure to be happy with your lot and remain where you are career-wise (at least for the time being, until the economic situation improves) is obvious. Given this current situation, the power in the employment relationship would appear to rest with the employing organization, in this case the multinational corporation. However, taking Foucault's perspective that the preservation of power exists only as long as it is adhered to by social actors, it could be suggested that this state of affairs is unstable. If structural market conditions improve to create a booming employment period, control based on concertive pressure would shift back to the employee, who then would not be as tied to the organization for work and financial security.

\section{Objective and Subjective Career - Empirical Findings}

The respondents perceived that their objective careers had suffered negatively by virtue of their location choice. For instance Angie (American, 41 yrs) noted that: 
In [company name] and in France . . . they pay us with the sunshine and the beautiful Côte D'Azur and the ten weeks of vacation, but there's still just [laugh] a money limit on salaries. That can be very annoying. I think financially [I] would have progressed [had I remained in the US].

This sentiment was echoed by Rick (English, 44 yrs): '[U]nless I was completely stupid, I'd be far better off financially and up [had I remained in England]. I think here you're trading location for career advancement and money. If you're not in Paris in France, then you're not in the right place.'

On the other hand, subjective elements apparently had a major role to play in the respondents' career location decisions. Milly (American, 34 yrs) noticed that free time is a big incentive:

Sundays, taking vacations ... They sound like little things but it's a completely different culture outlook for me, from being American. ... I mean even ... on vacation ... you'd still be expected to carry your mobile and take your [laptop] ... And here [France] I mean you're on vacation you know. And that's a big difference.

Similarly, Francis (Irish, 33 yrs) actually turned down a promotional position in order to work in a technical area that was particularly exciting to him, where he could learn innovative skills that would be easily transferable in a buoyant employment market:

I was more interested in what work I was doing on a day to day basis and being team lead wouldn't change that. .. . [C]hanging job[s] horizontally set me back probably . . . in terms of the hierarchy. It helped me out in terms of the CV, because I got to do stuff that ... looks really good on a CV, so I'm very happy about that.

Here, learning and self-development were given priority over organizational advancement. This example also underlines the recognition by the interviewees of the importance of having transferable skills in an open job market, suggesting the transactional nature of the current employment contract.

Wider factors in individuals' lives - life stage, marital/parental status - all play a part in building up their respective protean career, which by definition, is unfixed and ever-changing, with significant life occurrences changing career priorities. This was evident from Shaun's (English, 39 yrs) comments: 'I mean to be honest if I was on my own here then I wouldn't think twice about going to [corporate headquarters location on assignment for a few years] . . . But I don't think I'd survive away from my family.'

Susan (English, 39 yrs) also gave a significant life occurrence (in her case 
the death of a close family member) as the catalyst in her reassessing her career priorities and taking a wider view of what were the most important things in her life:

I'm not particularly interested in middle management or rising up a ladder in a corporation, purely because in my [travel agency] job I was a middle manager and ... you get the worst from both ends - the directors are pulling you one way and then all the staff are pulling you another. And I really found that the job ... could get very very stressful ... [I]t got to the point where I . . started to not like it. ... And plus the fact I have a very different attitude now because my father died when I was 25 and before he died my mentality was go it alone, you don't think of anything else outside of just getting ... a job and proving ... Now a death in the family of a very close loved one really completely changes your outlook of how you should be living your life and it makes you wake up ... to say "hang on, am I enjoying this?" And so now I tend to really live my life where ... money isn't, obviously you need enough to survive, but it's not the be all and end all.

Kate (English, 38 yrs) also experienced a significant life occurrence when she was made redundant, which changed her career outlook:

Before we were closed I wanted to be the next level up: I was senior manager and the next level up was ... partner and I was ... keen to do that. But looking back that would have been selling your soul really, the amount of work you have to put in. Now I'm not quite so keen. I want to be able to do my job and enjoy it, but also have some time for myself which I'd never had before, and enjoy the kids.

Billy (Welsh, 52 yrs) also consciously chose to prioritize his family over an ambitious career, here exercising his individual control over his protean career:

I think you have to take a choice at some time in your career: either you want to stay around your family or you decide to, you want to make a career. And ... so my choice was to stay around my family, to avoid traveling if I could. So that limited my career path ... I mean the social and the family life is essential, and that over-rides my professional life, any kind of career move.

These examples describe the three key elements in a protean career: autonomy (for example having control over one's working life), personal value (for example prioritizing personal goals over organizational goals), and psychological success (for example feeling content in oneself). We noted previously in the chapter that Starkey and McKinlay (1998) found Foucault's later work to emphasize more the technologies of the self to actualize desires. From the research shared in this chapter, the individuals' desires and personal priorities seem to take precedence over organizational 
roles or objective career elements. This suggests that the ultimate power over career rests with the individuals in question, and the priorities here are subject to continuous change over time, as new experiences and significant life occurrences impact on individuals' lives.

\title{
Career, Power and Control - Empirical Findings on the Shift to Managing Your Own Career
}

Some individuals in the research sample acknowledged their special treatment with their organization managing their career for them: 'I mean only last week I was on an assessment centre for 3 days. . . . And that's part of the career development program for me personally. But I'm one of the exceptions. I know not everyone's being treated like this' (Shaun, English, 39 yrs). However, the majority realized that they have to be proactive in taking care of their own career. The following quote from Billy (Welsh, 52 yrs) outlined this:

\begin{abstract}
It's been very much a question of me looking after it myself . . . I do get training but it's always down to myself . . . to initiate the steps to move forward. . . . It was very clear to me . . up until . . early 90 s when the company was going very strongly that there was well an initiative to go to training, to be trained, to move forward, there were opportunities to move forward ... and . . . there were opportunities opening all the time. Since the mid 90s it's been very difficult because the company's been shrunk, opportunities are less and less. . . . It's a question of you wanting to go out and get it rather than the company forcing it down your neck. So it's very much left to the individual.
\end{abstract}

This would suggest individuals' increased governmentality of their careers, mainly without the assistance and guidance of the organization. While this could be seen as individual power over organizational control, the slackening of organizational control over their employees' careers may in some cases also render the psychological contract more transactional in nature. But the converse may also be true. There is also an issue here for those employees needing organizational guidance to further their career and their lack of control given that they are not offered opportunities for career progression, but have to proactively fight for them. Thus, the personal character of employees plays a major part in determining whether or not they get to advance in the organization; that is whether or not they are vocal and visible enough. This could suggest a lack of diversity (in character, personality) of individuals within organizations who are following an organizational career, which would potentially have repercussions on the organization in the future, particularly for multinational organizations that need to cater to diverse cultural groupings and vast numbers of employees. 


\section{PRACTICAL IMPLICATIONS FOR HUMAN RESOURCES PROFESSIONALS ${ }^{5}$}

Given our argument in this chapter that careers are becoming more individual, with people consciously involved (to a greater or lesser degree depending on the individual) in the control of their own careers within the framework of their whole-life system, this chapter proposes the protean career as the career path that is being increasingly pursued by the individuals within multinational organizations that were sampled in this research. The protean career underlies the complexity of career planning and guidance for professionals, particularly in an international space. While aptitude and personality testing aid professionals in advising their clients on future career directions to which they might be more suited, other externalities play a major role. Location, financial reward, free time and work flexibility (tele-working, flexi-time, part-time work) are some elements which clients or employees seeking career advice may determine more important to them than meeting their work-centered abilities. The research conducted and shared in this chapter stresses the 'other' factors that must be considered in career advice for individuals. Such an approach is spreading among so-called life coaches (life/career coaches) (Ballinger 2003; McCormick 2005; McIntosh 2003). A more detailed overview of the client/employee's life, roles and goals needs to be weighed against aptitude, experience and opportunity. The following model has been developed from the interview data as a working guide for HR practitioners to use when advising employees/clients about their career.

\section{Explanation of the Model}

This model presents a simplified overview of the primary career influences that affect an individual's career choices and decision making. These categories and examples stemmed from the inductive research undertaken. Note that the examples listed alongside each of the career influencers in this model are neither definitive nor exhaustive. Indeed it is expected that the elements corresponding with each influencer will never be definitive or exhausted, but evolving. The key to the model is that a different item (or items) under a different influencer (or influencers) will be the main career determinant(s) at different points over the individual's life (over time, life stage, age), changing due to significant life occurrences (such as the birth of a child, marriage, separation, ill health) or circumstance (such as redundancy). The aim of the model is to depict the non-mutually exclusive nature of career influencers, with each influencer (as it affects the individual) requiring consideration in career guidance advice. What is emerging from 
Table 19.2 Simplified model of primary career influencers based on research findings

\begin{tabular}{|c|c|}
\hline $\begin{array}{l}\text { Primary Career } \\
\text { Influencers* }\end{array}$ & Dependent on (examples, not exclusive) \\
\hline $\begin{array}{l}\text { Individual } \\
\text { 'I am fulfilled' }\end{array}$ & $\begin{array}{l}\text { Personality (openness to working in another country/ } \\
\text { culture, tolerance, dedication, perseverance...) } \\
\text { Motivations, visions, goals (ambition, work/life } \\
\text { priorities) }\end{array}$ \\
\hline $\begin{array}{l}\text { Family situation } \\
\text { 'work/life } \\
\text { balance' }\end{array}$ & $\begin{array}{l}\text { Spouse/partner (dual career, trailing spouse, single } \\
\text { income. . .) } \\
\text { Children (ages, schooling) } \\
\text { Extended family dependents }\end{array}$ \\
\hline $\begin{array}{l}\text { Organization } \\
\text { 'where, with } \\
\text { whom I work' }\end{array}$ & $\begin{array}{l}\text { Structure (flat or hierarchical, domestic, multinational) } \\
\text { Intra-organization mobility (open systems, blocked by } \\
\text { management) } \\
\text { Power (line manager, HR. . .) } \\
\text { Politics (gender, ageism, networks, social capital) } \\
\text { Organization culture (informal, individualistic, collective, } \\
\text { team work, open door) }\end{array}$ \\
\hline $\begin{array}{l}\text { Job } \\
\text { 'I love my job' }\end{array}$ & $\begin{array}{l}\text { Technical ability (suitability to the job/aptitude) } \\
\text { Work preferences (individual or in a group) } \\
\text { Enthusiasm/interest (hobby, job) } \\
\text { Learning (ongoing challenge, change) } \\
\text { Travel (desire to travel with job) }\end{array}$ \\
\hline $\begin{array}{l}\text { Society } \\
\text { 'what others } \\
\text { think' }\end{array}$ & $\begin{array}{l}\text { Social groupings (membership of professional associations, } \\
\text { informal social societies) } \\
\text { Perception of individual among peers, among social group }\end{array}$ \\
\hline $\begin{array}{l}\text { Country } \\
\text { 'context' }\end{array}$ & $\begin{array}{l}\text { Legal (employment law) } \\
\text { Language } \\
\text { Social welfare (unemployment benefit, childcare } \\
\text { support. . ) } \\
\text { Economic situation (labour market) }\end{array}$ \\
\hline
\end{tabular}

Note: *The prioritization of these primary career influencers changes and evolves over time due to age/life stage, significant life occurrence and circumstances.

this research is that the expectations of control typically implied by such practices as career counseling and organizational career planning, training and development may be based on more tenuous foundations than their prevalence in the HRM departments of multinational corporations would imply. 


\section{CONCLUSION}

This chapter focuses on individuals' perceptions of power and control in relation to their pursuit of an international career as locally hired foreigners. The material shared here is part of a wider research undertaken on the international career, in which we question the notion of the 'expatriate' as someone who is initially positioned, then moved, then returned to home territory, and in which the major decisions are organizational rather than individual. We find the notion of the protean career more insightful than that of the 'expatriate experience'.

This chapter offers a critical perspective to contemporary literature on the international career. We have taken findings from an in-depth qualitative study of a sample of international assignees, the self-initiated, permanent international assignee. In relation to other groups, this group has been relatively neglected. Both agency and structure are found to be relevant concerning the choice (or lack of choice) that an individual has in following an international career path. Thus our findings are consistent with Archer's notion of the 'inner conversation', when she states that 'agents monitor themselves within situations and initiate courses of action in the light of their concerns, including modifying their projects according to circumstances that they confront' (Archer 2003, p. 300, original italics). While individualism in seeking to follow a career over which one has control has been proclaimed in the findings of this study, the relevance of structural forces influencing international movement (such as the respective labor market economies and employment, restrictions to migration or promotion of migration) cannot be ignored. The impact of such structural elements on individuals' agency is dependent on the individual's characteristics. A major obstacle to grasping control over one's career and life is economically-based. Financial security plays a large part, potentially limiting the freedom of a totally subjective career, while in turn binding the individual to an organization for financial protection. This is particularly noticeable at different life stages, across gender, and within the economic climate of employment insecurity (redundancies and closures). The protean career concept embodies the total picture of an individual's career influencers and is a key concept to be referenced and used by HR practitioners in career guidance advisory roles. It implies that the nature of 'career' itself changes at different stages of a specific career.

Contemporary career theory notes the 'need to tailor psychological contractual conditions to the specific needs of the individual' (Larsen and Ellehave 2000, p. 114). This mirrors Swart and Kinnie's conclusion (2004) that for organizations to adopt a uniform, one size fits all approach to career management is not sufficient. Bailyn and Schein (1980) believe 
that organizations need to 'think more creatively about the various kinds of people carrying on careers within them, with the goal of providing the possibility of career satisfaction for all and thus increasing the effectiveness of the technical, professional, and managerial workforce' (pp. 70-71). This underlines the requirement for different individual career alternatives to be discussed in career management sessions, and implies that HR professionals need to adopt a broader approach to career management in collaboration with their employees or clients.

\section{NOTES}

1. Where expatriate is broadly defined as 'the process of an individual moving to live in a different country' (Brewster, 2002: 84).

2. The information regarding companies and employees in the Sophia Antipolis park was taken from the official Sophia Antipolis website: http://www.sophia-antipolis.org/ $\mathrm{GB} /$ sophia-antipolis/sophia-antipilis/presentation-generale/presentation-generale.htm, 27 November 2008.

3. The use of personal contacts in gaining access to research candidates has been advocated in research literature (Beynon 1988, pp. 21-33; Bresnen 1988, pp. 38-39; Buchanan et al. 1988 , p. 56; Crompton and Jones 1988, pp. 68-70).

4. The ellipses in the quotations indicate pauses, not omitted material.

5. Under this category of HR professionals we include HR practitioners within the employing multinational organizations, as well as external career coaches, outplacement organizations and so on.

\section{REFERENCES}

Adler, N. (1986), International Dimensions of Organizational Behavior, Boston, MA: PWS Kent Publishing.

Archer, M. (2003), Structure, Agency and the Internal Conversation, Cambridge: Cambridge University Press.

Ashforth, B. and R.H. Humphrey (1993), 'Emotional labour in service roles: the influence of identity', Academy of Management Review, 18(1), 88-115.

Bailyn, L. and E.H. Schein (1980), Living with Technology: Issues at Mid Career, Cambridge, MA and London, England: The MIT Press.

Ballinger, L. (2003), 'Life coaches', The Observer, 12 January, http://observer. guardian.co.uk/cash/story/0,6903,872835,00.html, accessed 7 November 2008.

Beynon, H. (1988), 'Regulating research: politics and decision making in industrial organizations', in A. Bryman (ed.), Doing Research in Organizations, London, England: Routledge, pp. 21-33.

Boyacigiller, N. (1995), 'The international assignment reconsidered', in M. Mendenhall and G. Oddou (eds), Readings and Cases in International Human Resource Management, Cincinnati, OH: South-Western College Publishing, pp. 149-156.

Braverman, H. (1974), Labor and Monopoly Capital: The Degradation of Work in the Twentieth Century, New York and London: Monthly Review Press. 
Bresnen, M. (1988), 'Insights on site: research into construction project organizations', in A. Bryman (ed.), Doing Research in Organizations, London, England: Routledge, pp. 34-52.

Brewster, C. (2002), 'Expatriation', in T. Redman and A. Wilkinson (eds) The Informed Student Guide to Human Resource Management, London: Thomson Learning.

Buchanan, D., D. Boddy and J. McCalman (1988), 'Getting in, getting on, getting out, and getting back', in Bryman, A. (ed.), Doing Research in Organizations, London, England: Routledge, pp. 53-67.

Crompton, R. and G. Jones (1988), 'Researching white collar organizations: why sociologists should not stop doing case studies', in A. Bryman (ed.), Doing Research in Organizations, London, England: Routledge, pp. 68-81.

Deetz, S. (1998), 'Discursive formations, strategized subordination and self surveillance', in A. McKinlay and K. Starkey (eds), Foucault, Management and Organization Theory, London: Sage, pp. 151-172.

Denzin, N. and Y.S. Lincoln (1998), Strategies of Qualitative Inquiry, Thousand Oaks, CA: Sage.

Dowling, P.J. and D.E. Welch (2004), International Human Resource Management: Managing People in a Multinational Context, London: Thomson Learning.

Feldman, D.C. and H.B. Tompson (1993), 'Expatriation, repatriation, and domestic geographical relocation: an empirical investigation of adjustment to new job assignments', Journal of International Business Studies, 24(3), 507-529.

Foucault, M. (1977), Discipline and Punish, Harmondsworth: Penguin.

Foucault, M. (1982), 'The subject and the power', in H. Dreyfus and P. Rabinow (eds), Michel Foucault: Beyond Structuralism and Hermeneutics, Brighton: Harvester, pp. 208-226.

Foucault, M. (1988), 'Technologies of the self', in L.H. Martin, H. Gutman and P.H. Hutton (eds), Technologies of the Self: A Seminar with Michel Foucault, Amherst, MA: University of Massachusetts Press, pp. 16-49.

Foucault, M. (1990), Politics, Philosophy, Culture: Interviews and Other Writings 1977-1984, New York: Routledge.

Giddens, A. (1979), Central Problems in Social Theory: Action, Structure and Contradiction in Social Analysis, London: Macmillan.

Giddens, A. (1993), New Rules of Sociological Method, Cambridge: Polity Press.

Glaser, B.G. and A.L. Strauss (1967), The Discovery of Grounded Theory: Strategies for Qualitative Research, Chicago, IL: Aldine.

Gratton, L. and V. Hope-Hailey (1999), "The rhetoric and reality of "new careers", in L. Gratton, V. Hope-Hailey, P. Stiles and C. Truss (eds), Strategic Human Resource Management: Corporate Rhetoric and Human Reality, London: Oxford University Press, pp. 79-100.

Hall, D.T. (1976), Careers in Organizations, Santa Monica, CA: Goodyear.

Hall, D.T. and B. Harrington (2004), 'Protean career', in Sloan Work and Family Research Network Work-Family Encyclopedia, 21 March, http://wfnetwork. bc.edu/encyclopedia_entry.php?id=249\&area $=$ academics, accessed 22 August 2007.

Hochschild, A. (1983), The Managed Heart: Commercialization of Human Feeling, Berkeley, CA: University of California Press.

Kahn, W.A. (1996), 'Secure base relationships at work', in D.T. Hall and Associates (eds), The Career is Dead-Long Live the Career, San Francisco, CA: Jossey-Bass, pp. 158-179. 
Larsen, H.H. and C.F. Ellehave (2000), 'Careers in organizations: theortical developments and empirical findings', in C. Brewster and H.H. Larsen (eds), Human Resource Management in Northern Europe, Oxford, UK: Blackwell Publishers Ltd, pp. 89-124.

Latour, B. (1986), 'The powers of association', in J. Law (ed.), Power, Action and Belief: A New Sociology of Knowledge, London: Routledge.

Mallon, M. (1999), 'Going “portfolio”: making sense of changing careers', Career Development International, 4(7), 358-69.

Martin, L.H., H. Gutman and P.H. Hutton (eds) (1988), Technologies of the Self: A Seminar with Michel Foucault, Amherst, MA: University of Massachusetts Press.

McCormick, A. (2005), 'Can't get no job satisfaction?' Bookseller, 7 January (5185), 49.

McIntosh, S. (2003), 'Work-life balance: how life coaching can help', Business Information Review, December, 20(4), 181-189.

McQueen, R. and C. Knussen (2002), Research Methods for Social Science: An Introduction, Harlow: Prentice Hall.

Mendenhall, M. and G. Oddou (2000), Readings and Cases in International Human Resource Management, Boston, MA: South-Western College Publishing.

Rose, N.S. (1996), Inventing Our Selves: Psychology, Power, and Personhood, Cambridge: Cambridge University Press.

Rousseau, D.M. (1995), Psychological Contracts in Organizations, Thousand Oaks, CA: Sage.

Stake, R.E. (1998), 'Case studies', in N. Denzin and Y.S. Lincoln (eds), Strategies of Qualitative Inquiry, Thousand Oaks, CA: Sage, pp. 86-109.

Starkey, K. and A. McKinlay (1998), 'Deconstructing organization: discipline and desire', in A. McKinlay and K. Starkey (eds), Foucault, Management, and Organization Theory, London: Sage.

Swart, J. and J. Kinnie (2004), Managing the Careers of Professional Knowledge Workers, London: CIPD.

Turner, R. (1976), 'The real self: from institution to impulse', American Journal of Sociology, 81(5), 989-1016.

Van Maanen, J. and E.H. Schein (1977), 'Career development', in J.J.R. Hackman and L. Suttle (eds), Improving Life at Work, Santa Monica, CA: Goodyear.

Weick, K.E. (1996), 'Enactment and the boundaryless career: organizing as we work', in M. Arthur and D.M. Rousseau (eds), Boundaryless Careers, Oxford: Oxford University Press, pp. 40-57.

Weick, K.E, and L.R. Berlinger (1989), 'Career improvisation in self-designing organizations', in M.B. Arthur, D.T. Hall and B.S. Lawrence (eds), The Handbook of Career Theory, Cambridge: Cambridge University Press, pp. 313-328. 
